NBER WORKING PAPER SERIES

\title{
FINANCIAL DEVELOPMENT AND CITY GROWTH: EVIDENCE FROM NORTHEASTERN AMERICAN CITIES, 1790-1870
}

\author{
Howard Bodenhorn \\ David Cuberes \\ Working Paper 15997 \\ http://www.nber.org/papers/w15997
NATIONAL BUREAU OF ECONOMIC RESEARCH
1050 Massachusetts Avenue
Cambridge, MA 02138

May 2010

\begin{abstract}
We thank Antonio Accetturo, Scott Baier, Tomas Cvrcek, Jeff Lin, Albert Saiz, Curtis Simon, and seminar participants at Brown University, University of the Basque Country, University of Sheffield, and participants in the Urban Economics Association Meetings in Denver, and the First Workshop on Urban Economics (University of Barcelona) for valuable comments on earlier drafts. Bodenhorn thanks the John Simon Guggenheim Foundation for financial support. We also thank Adam Blott, Laura Lamontagne and Pam Bodenhorn for their assistance in collecting and organizing the data. The views expressed herein are those of the authors and do not necessarily reflect the views of the National Bureau of Economic Research.
\end{abstract}

NBER working papers are circulated for discussion and comment purposes. They have not been peerreviewed or been subject to the review by the NBER Board of Directors that accompanies official NBER publications.

(C) 2010 by Howard Bodenhorn and David Cuberes. All rights reserved. Short sections of text, not to exceed two paragraphs, may be quoted without explicit permission provided that full credit, including (C) notice, is given to the source. 
Financial Development and City Growth: Evidence from Northeastern American Cities, 1790-1870 Howard Bodenhorn and David Cuberes

NBER Working Paper No. 15997

May 2010, Revised February 2014

JEL No. N11,N90,R11

\begin{abstract}
$\underline{\text { ABSTRACT }}$
In this paper we argue that in 19th century U.S, households and firms that were located in cities with banks enjoyed a higher level of both consumption and production amenities than those who were located in cities without banks. We use data on banks location and city population growth in the Northeastern United States in 1830-1870 and document a positive and strong correlation between financial development and subsequent population growth. The correlation is robust to controls for geographical characteristics of the city, the percentage of population working in different sectors, and its initial population. Propensity score matching estimators that compare similar cities in terms of observables also yield a positive association between finance and urban growth. Our estimates suggest that the presence of a bank at a given location in the late $1830 \mathrm{~s}$ is associated with increases its population growth in the $1840 \mathrm{~s}$ by one to one and a half percentage points per year. Because urban growth was correlated with economic development in the nineteenth-century U.S, we believe our results provide further support for the financegrowth nexus.
\end{abstract}

Howard Bodenhorn

John E. Walker Department of Economics

College of Business and Behavioral Science

201-B Sirrine Hall

Clemson University

Clemson, SC 29634

and NBER

bodenhorn@gmail.com

David Cuberes

Department of Economics

University of Sheffield

9 Mappin St

Sheffield S1 4DT

United Kingdom

d.cuberes@sheffield.ac.uk 


\section{Introduction}

In 1820 the place that was to become Rochester, New York was not even an incorporated village, so its population was not separately recorded in that year's federal census. One contemporary, in fact, described it as a "Godforsaken place inhabited by muskrats" (Berstein 2005, 272). A decade later, the town had 13,000 residents and in 1870 Rochester's population exceeded 62,300. Between 1830 and 1870, Rochester's population grew, on average by more than 3 persons per day. Although several New York towns - notably Buffalo, Poughkeepsie, Newburgh, Ogdensburgh and Oswego -- grew at rates comparable to Rochester's, population decline was as common as growth among towns with between 2,500 and 5,000 residents in 1830; 115 towns experienced population growth, 100 experienced declines. Some of the observed differences in growth can be explained by geographic or political good fortune. The Erie Canal, for example, was an important determinant of city and town growth after 1825. Lockport and Syracuse, among others, grew after the canal connected them to the state's other commercial towns and villages. But some towns with seemingly promising futures were bypassed by the canal declined into obscurity. An unresolved issue is the extent to which economic forces other than canals, railroads or other transportation infrastructure influenced urban growth in the nineteenth-century United States.

We empirically investigate this question by examining city and town population growth in nine northeastern states (Connecticut, Delaware, Massachusetts, New Hampshire, New Jersey, New York, Pennsylvania, Rhode Island, and Vermont) and relate that growth to geographic factors, local industry, the places' importance as governmental and commercial centers, and other measurable features. Economic historians have an enduring interest in urban growth and development. Beeson et al (2001) show that long-run population growth at the county level was related to resource endowments, access to waterways and other transportation facilities, local climate, and human capital investments. Simon and Nardinelli (2002), too, find evidence that, after controlling for industrial mix and access to waterways, places with more initial human capital grew more rapidly up to 1990. Their result is broadly consistent with Kim's (2000) finding that cities with larger proportionate share of employment in trade and services grew larger than cities with a larger initial fraction of the population employed in manufacturing. 
Our study adopts a similar approach to these articles but our focus is the relative importance of local financial development as an independent source of growth. The link between finance and urbanization is also of enduring interest to economists and economic historians. Among economic historians, Ashmead (1914), Taylor (1967), Kroos (1967), Weiman (1988) and Crothers (1999) point to the important role banks played in nineteenth-century urban development, mostly through the banks' encouragement of entrepreneurship, but little direct evidence has been brought to bear on the issue. Lacking systematic evidence on the connection and based solely on the experience of America's largest cities, Kroos (1967) observed that some "cities were more aggressive in expanding their financial institutions ... [but only] a daring generalizer would say that these slight differences had something to do with the way ... cities grew." A recent empirical investigation of the nineteenth-century United States, however, finds that "slight differences" had profound effects. Jaremski and Rousseau (2013) show that the urbanization rate in counties with banks in 1850 increased between 6 and $11 \%$ in the subsequent decade.

Our paper sheds additional light on the association between finance and urbanization through an investigation of local financial development and population growth in nineteenthcentury northeastern United States. Our results point toward a positive impact of banking on subsequent town growth. OLS and propensity score matching estimates reveal that towns with banks grew at compound annual average rates about 1 to 1.7 percentage points greater than towns without banks. Using bank assets as an alternative measure of financial development, we show that a one standard deviation increase in bank assets (3.3) is associated with a 0.33 percentage point increase in subsequent population growth over the ensuing three decades. Credit availability represented an important element of urbanization.

It is hard to imagine that, on average, cities and towns that experienced financial development would not subsequently grow, but there is no shortage of counterexamples - places with banks that failed to take off. With a chartered, commercial bank opening in 1818 and its population having more than doubled between 1800 and 1820, Cherry Valley, New York's 3,500 residents in 1820 must have considered the town's future to be bright indeed. The village had one of just 33 commercial banks chartered in New York before 1820, and one of approximately a score of banks outside Albany and New York City (Weber 2011a). But not being on a river and bypassed by the canal, Cherry Valley in 1870 was a declining, increasingly obscure place with 
less than 2,400 residents. In 2010, the village had just 520 residents. Local finance could not overcome powerful, longer-term economic and geographic factors that worked against urban development in upstate New York and elsewhere. The issue examined here is the extent to which financial development - on average - positively influenced growth. What we measure is the extent to which finance incrementally influenced urban development across a cross-section of northeastern US towns in the early stages of development.

In addition to improving our understanding of historical processes of urbanization, this paper also contributes to an economic literature dating back, at least, to Alfred Marshall (1895, pp. 41-43), which posits a connection between business starts, entrepreneurship and urban growth. Entrepreneurship depends on four elements: sufficient market size; information sharing; political and social institutions that encourage entrepreneurial activities; and access to critical inputs, including finance. Chinitz (1961) contends that local differences in urban economic dynamism are correlated with the local availability of capital. Capital, while fungible, is not perfectly mobile across space. The cost of capital even in the twenty-first century is not invariant to the location of buyer or seller; it was definitely not invariant to location in the nineteenth century (Chen et al. 2010). ${ }^{1}$ When Charles and Escol Sellers relocated their manufacturing enterprise from Philadelphia to Cincinnati in the 1840s, one disadvantage of Cincinnati was "not having capital" in the same supply as in Philadelphia (Vitiello 2013, 57-58). They regularly travelled east to secure financing. "Once we admit of such immobility," writes Chinitz (1961, p. 285), "it becomes relevant to inquire into differences in local capital supply among areas" when inquiring into the long-term growth of cities. Glaeser et al. (2010, p. 7), too, contend that entrepreneurial dynamism is critical to urban growth and "no input is more important for new entrepreneurs than finance itself." Although some papers have attempted to study the link between entrepreneurship and city growth (Glaeser et al 1992, Cingano and Schivardi 2004, Glaeser and Kerr 2009), to our knowledge, we are the first to directly explore the historical role played by banks on city growth.

Our paper provides evidence consistent with these interpretations of the connection between finance, entrepreneurship, and urbanization. While we do not directly explore the entrepreneurship-urbanization nexus, the connections we observe between finance and urban

\footnotetext{
${ }^{1}$ Bodenhorn (1992) and Bodenhorn and Rockoff (1992) show that regional interest rates on short-term commercial paper were modest and declining throughout the antebellum era, but long-term capital appears to have been less mobile.
} 
growth are consistent with existing evidence on the entrepreneurial nexus. Duranton and Puga (2013a) provide a comprehensive review of studies that have attempted to explain the main factors driving city growth. They conclude that the most important drivers of city growth are urban amenities like good weather (Glaeser et al, 2001) or more general ones (Glaeser et al 2001, Albouy 2008, Carlino and Saiz 2008), agglomeration economies (Ciccone and Hall 1996, Combes et al. 2010), human capital (Glaeser et al. 1995, Simon and Nardinelli 1996, 2002, Glaeser and Saiz 2004), and city-specific shocks (Duranton and Puga 2013b).

Our paper also indirectly contributes to the finance-growth literature. Despite the many difficulties involved in identifying causal effects, the weight of evidence supports the hypothesis that finance positively affects growth. Demirguc-Kunt and Levine (2001) and Levine (1997; 2005) argue that the existing research suggests that places with better functioning banks and financial markets experience higher rates of economic growth. The weight of the evidence suggests that more efficient financial sectors mitigate external financing costs and constraints that retard growth. Easing financial constraints by increasing the local availability of lendable funds encourages growth, most likely by encouraging innovation and entrepreneurship (Benfratello et al. 2008; Kendall 2012). Fulford (2012) shows that banking's effects also extend beyond industrial entrepreneurship; proximity to a bank in the National Banking era increased land under cultivation and improved agricultural yields. While population growth and increasing urban density may proxy for economic growth, we are more interested in urbanization and town and city growth per se. Urbanization is an integral feature of modernization and deserves to be better understood in its own right. Our results are, therefore, of more than historical interest. While historical in nature, they provide insights into connections between urbanization and modernization and reflect on the development process more generally.

\section{Conceptual framework}

In this section we provide a parsimonious, theoretical framework for our empirical analysis that extends Glaeser, Scheinkman and Shleifer's (1995) approach. Cities are treated as separate economies that share a common pool of mobile labor, so that differences in city growth are not due to exogenous labor endowments. The assumption of mobile labor means that cities differ in their levels of technological productivity, quality of life and quantity of capital. Total 
output in city $j$ at time $t$ is given by the increasing returns to scale Cobb-Douglas production function of the following form:

$$
Y_{j t}=A_{j t} L_{j t}^{\alpha} K_{j t}^{\beta}
$$

where $A_{j t}$ is the standard Solow-style productivity shift factor of city $j$ at time $t ; L_{j t}$ is the population (or labor supply) of city $j$ at time $t ; K_{j t}$ is capital utilized in city $j$ at time $t$; and $0<$ $\alpha, \beta<1$ are national production parameters common across cities. Following the urban economics literature, we assume large cities, i.e. cities with a large number of workers, capital, or both - have a productivity advantage due to some agglomeration economy in production. ${ }^{2}$ For instance, firms in larger cities may be more productive because they have access to a large pool of workers or can learn from each other (see Duranton and Puga, 2004 for a detailed taxonomy of agglomeration economies and their microfoundations). On the other hand, cities have access to a common production technology in labor and capital, subject to idiosyncratic productivity shocks.

Residents of each city experience a quality of life $Q$ that, we assume, is a positive function of the consumption amenities that the city offers $(B)$ and a negative function of the city's population $(L)$, which proxies congestion costs. The assumption that quality of life increases with urban amenities is consistent with the standard monocentric model (Alonso, 1964; Mills, 1967; and Muth, 1969) in which urban dwellers experience an increase in utility with an increase in consumption amenities. With respect to congestion forces, we adopt a parsimonious functional form that reflects congestion effects due to such factors as higher crime rates and housing costs, as well as more crowding in public goods use in more densely populated cities. For expositional ease, we assume that congestion effects $g(L)$ reduce the quality of life as city size increases: ${ }^{3}$

$$
Q(B), L)=B_{j t}^{\xi} L_{j t}^{-\delta}
$$

\footnotetext{
${ }^{2}$ In our framework this can be either reflected on a larger value of $A$ bigger cities or by assuming that there are increasing returns to scale in production, i.e. $\alpha+\beta>1$. See, for instance, Cuberes (2009) for a mode that assumes the latter.

${ }^{3}$ In a more sophisticated model one could argue that amenities, and therefore quality of life, increase with population, at least over some range. For example, more populated or denser cities offer better networks and facilitate the exchange of ideas among urban dwellers. For simplicity, we abstract from this possibility in our illustrative model.
} 
where $\xi, \delta>0$. Total utility of potential residents is assumed to be a function of their labor income and the quality of life each person realizes in city $j$ and time $t$. Assuming that wages are competitively determined, utility can be expressed as the product of the wage (marginal product of labor) and the quality of life index:

$$
U_{j t}=\alpha A_{j t} B_{j t}^{\xi} L_{j t}^{\alpha-1-\delta} K_{j t}^{\beta}
$$

In a spatial equilibrium, if potential migrants can freely and costlessly relocate, it must be the case that each individual's utility level in any and every city equals his or her reservation utility at time $t$, which is denoted as $\hat{U}_{t}$. These assumptions yield the following growth equation:

$\log \left(\hat{U}_{t+1} / \hat{U}_{t}\right)=\log \left(A_{j t+1} / A_{j t}\right)+\xi \log \left(B_{j t+1} / B_{j t}\right)+(\alpha-1-\delta) \log \left(L_{j t+1} / L_{j t}\right)+\beta \log \left(K_{j t+1} / K_{j t}\right)$

To parametrize the model, we also assume:

$$
\begin{aligned}
& \log \left(A_{j t+1} / A_{j t}\right)=X_{j t}^{\prime} \Gamma+\varepsilon_{j t+1} \\
& \log \left(B_{j t+1} / B_{j t}\right)=Z_{j t}^{\prime} \Theta+\zeta_{j t+1} \\
& \log \left(K_{j t+1} / K_{j t}\right)=X_{j t}^{\prime} \Pi+\eta_{j t+1}
\end{aligned}
$$

where $X_{j t}$ is a vector of city characteristics at time $t$ that influence both the growth of city-level productivity and capital, $Z_{j t}$ is a vector of amenities, and $\varepsilon_{j t+1}$ and $\eta_{j t+l}$ are error terms that capture omitted variables that may affect technological progress and capital accumulation, respectively. $\Gamma$, $\Theta$ and $\Pi$ are vectors of parameters. Combining equations (4)-(7) yields:

$$
\log \left(L_{j t+1} / L_{j t}\right)=X_{j t}^{\prime} \Psi+Z_{j t}^{\prime} \Omega+\mu_{t}+u_{j t+1}
$$

where $\Psi \equiv(\Gamma+\beta \Pi) /(\alpha-1-\delta), \Omega \equiv \xi \Theta /(\alpha-1-\delta), \mu_{t} \equiv-\log \left(\hat{U}_{t+1} / \hat{U}_{t}\right) /(\alpha-1-\delta)$, and $u_{j t+1} \equiv\left(\varepsilon_{j t+1}+\xi \zeta_{j t+1}+\right.$ $\left.\beta \eta_{j t+1}\right) /(\alpha-1-\delta)$ is an error term uncorrelated with city characteristics. Equation (8) implies that 
estimated growth regression coefficients on the city-level variables ( $X$ 's and $Z$ 's) are a combination of the underlying productivity and quality of life, as well as capital intensity, coefficients. $^{4}$

Our principal empirical concern is whether the availability of financial services influences urban growth and development. In our theoretical framework we assume that finance is both a consumer's and a producer's amenity. In consumption, a bank offers a safe repository for savings, which facilitates consumers' abilities to smooth consumption across time (Allen and Gale 1997). As a productive amenity, finance may influence growth through either of two channels, both of which appear in the finance-growth literature (Levine 1997). First, banks stimulate capital accumulation in cities by providing funds for firms to invest. Second, they increase cities' entrepreneurial productivity (Schumpeter 1934). They do so by screening projects and lending to those they consider more profitable, which should encourage a selection of the most efficient entrepreneurs among the entrepreneurial class, and lead to more remunerative employment opportunities for the working class. An efficient, functioning banking system gathers information on idiosyncratic projects pursued by firms too small to issue debt in arms-length markets, allocates capital to the most promising ones, monitors borrowers over the life of the project, and forecloses on assets when projects prove unprofitable (Diamond 1984; Diamond 1991). In short, as part of a wider array of financial services, banks matter because they improve capital allocation and increase the marginal product of capital.

Following standard practice in the growth literature, we allow for (conditional) population convergence over the long run (Beeson et al 2001). Theoretically, convergence implies a negative correlation between initial population and population growth and may result either from (1) technology advancing more quickly in smaller towns than larger cities, or (2) migration from previously high- to previously low-growth regions due to reductions in quality of life in high-growth areas (Barro and Sala-i-Martin 1992; Glaeser and Gottlieb 2011). As Glaeser, Scheinkman and Shleifer (1995, p. 121) note, residents of rapidly growing cities may suffer reduced quality of life if urban infrastructure is slow to adjust to rapid increases in population. The combination of crowded tenements and poor sanitation, for example, led to a rising incidence of infectious disease and declining life expectancies in urbanizing, nineteenth-century

\footnotetext{
${ }^{4}$ Using a different model, Duranton and Puga (2013a) derive an empirical specification of a growth equation similar to ours.
} 
America (Haines 2001). While not quite Dickensian in nature, America's nineteenth-century cities were unhealthful, sometimes dangerous places. Ill health, declining life expectancy, and crime represent three consequential congestion effects evident in the era's medium to large cities, and may have been factors influencing migration between cities and towns.

\section{Data and Descriptive Statistics}

Mandated by the US Constitution, the US Census Bureau, or its predecessors, collected data on the population of cities, towns and villages - labeled "minor civil divisions" - every ten years beginning in 1790. The data are available in published census volumes (except for the census of 1810, in which the county is the smallest political unit for which information was published). Haines (2006) digitized these series in separate files for each year. We merged the files for each census year between 1790 and 1870 and corrected errors uncovered as we worked with the data. Over time, the names of some towns and villages changed and county boundaries were redrawn, though few substantial changes occurred after 1835 . We used various sources to track changes in place names and to consistently attribute populations to their appropriate places. The state of New York also conducted decennial censuses midway between the federal censuses and we used these data to check on the accuracy of data included in the federal census files. ${ }^{5}$

We use the reported populations of minor civil divisions at census years to construct population growth rates, which is the dependent variable of primary interest. Unlike other studies we include all minor civil divisions - villages, towns and cities - in the analysis. Beeson et al (2002) argue that an initial filter for cities and/or substantial urban places introduces selection bias into the results. The inclusion of only already established cities may not capture the full effects of natural and man-made factors on the emergence of urban places because a singular focus on already established cities constrains the analysis of growth to places that are already relatively large and prosperous. Such an approach does not well suit a world with places like Rochester and Syracuse, or places where only wildcats roamed just a few years before they emerged as towns. Beeson et al (2001) avoid this by focusing on county-level population growth to (imperfectly) account for the rise of suburbs in the mid-twentieth century. Our analysis stops

\footnotetext{
${ }^{5}$ Changes in spellings, misspellings, two or more towns in one state with the same name, and the inclusion of city wards meant that merging the files required a lot of inspection and cleaning. Combining the separate census files and then adding the banking data was a nontrivial exercise.
} 
at 1870 , well before the rise of extensive suburbanization so we focus on the smallest observed administrative census unit, which we hereafter label the "town."

Our study concludes at 1870 for several reasons. First, three decades (1840-1870) provide a sufficient window to investigate the medium- to long-term consequences of financial development on urbanization. Second, while railroads were being built by the 1850 s, it was only toward the end of our period of interest that railroads challenged the region's extensive canal system as the principal transporter of goods. ${ }^{6}$ Third, Civil War-era national banking acts completely reshaped the financial sector. Between the closing of the Second Bank of the United States (1836) and passage of the National Banking Acts (1863 and 1864), which created the Comptroller of the Currency as the system's regulator, banking policy devolved to the states. Although state-chartered banking continued after 1863, the federal tax imposed on note issues of state banks that took effect in July 1866 encouraged banks to change from state to federal charters. These, and other economic, financial and demographic changes occurring in the decades after the end of the US Civil War, suggested 1870 as a reasonable end date for our study.

Statistics reported in Panel A of Table 1 show that the middle of the nineteenth century is an interesting period for the study of town growth in the Northeast. In 1820 there were only seven places with more than 10,000 inhabitants. In 1840 there were 23 such places; in 1870 there were 108, and Brooklyn and Boston joined New York and Philadelphia as cities with more than 250,000 inhabitants. But the most significant change, perhaps, was in places with 25,000 to 50,000 people, which were dominated by mill towns such as Springfield, Lowell and Worcester, Massachusetts, transportation hubs such as Syracuse, New York and manufacturing towns close to the coal fields such as Scranton, Pennsylvania. Panel B reveals that manufacturing and commerce were, in fact, important sectors in towns of all sizes. The 1820 and 1840 census values are not directly comparable, but they offer some insights into sectoral employment in emerging towns. ${ }^{7}$ The 1840 values reveal that the share of the labor force employed in manufacturing and commerce increased (nonlinearly) in town size. For example, only about 3 percent were employed in trade and commerce in the smallest towns; approximately one-fourth of workers in

\footnotetext{
${ }^{6}$ In the early 1850s, New York's canals carried more than 10 times the tonnage carried by railroads. In 1860 the canal system moved about 4 million tons of goods per year, while the rail system moved about 3.5 million tons (French 1860).

${ }^{7}$ The 1820 census reported just three employments: agriculture, manufacturing and commerce. The 1840 census reported seven occupations: agriculture, manufacturing, commerce, mining, inland navigation, ocean navigation, and professional.
} 
Boston, Brooklyn, New York City and Philadelphia were. Cities and towns in the Northeast experienced dramatic changes in size and economic activity between 1820 and 1870, Our objective is to better understand how finance contributed to these changes.

Thus our correlate of principal interest is financial development, which we measure in several ways: whether the town had a bank (dummy variable equals one if town has one or more banks), the natural logarithm of assets, the dollar value of assets per capita, and bank money per capita. In the regressions we use the value measured at the beginning of the relevant period (hereafter "initial value"). These data are drawn from Weber (2011a, 2011b). Weber (2011a) created a census of banks, which includes each bank's town of operation, as well as its beginning and end dates. Weber (2011b) reports the balance sheets of all banks for which such information is available. Prior to 1830 , some of the earliest chartered banks failed to provide balance sheets to legislative committees, so pre-1830 reports are incomplete. Our inspection of Weber's (2011b) balance sheets suggests that by the late 1830s the data are reasonably complete so our initial census year is 1840 and we use bank data from the late 1830s (1837-39) as the initial bank year.

We focus on two balance sheet entries (assets and bank money), which are highly correlated with alternative measures, such as invested capital and loans, that capture two features of banking that reflect on finance's effects on growth. The stylized model above connects capital with growth and we posit that capital, especially working capital, and finance were closely connected at mid-century. Nineteenth-century banks loaned against collateral for working capital employed by merchants and manufacturers and their principal assets were short-term loans to businesses. But, recognizing that some banks held mortgages and other assets that may have financed productive investment, we use the more inclusive measure. Because we have no strong prior about how assets influenced growth, we offer alternative estimates using the natural logarithm of assets, as well as assets per capita. Our final measure reflects one of the principal functions of banks in at mid-century, which was the provision of money, measured as bank money (deposits + banknotes in circulation) per capita. It is well known that the nature of savings changes as finance arrives. In the absence of financial instruments, households in developing economies tend to save real assets, such as livestock, crop inventories, and land improvements. Finance affords at least some households the opportunity to diversify their savings into real and financial capital. In the early and mid-nineteenth century, the choice was not between diversified mutual funds and real property; it was between cash balances and real 
property. The Shaw (1973) and McKinnon (1973) models of financial development hold that money holdings and real capital accumulation are complementary in the early stages of development. The emergence of banks and bank-supplied currency directly affected the rate of capital accumulation, which influenced urbanization and modernization. More monetized local economies are expected to have grown more quickly. ${ }^{8}$

In the modern world, banks and bank offices are ubiquitous - busy intersections, strip malls, in Walmart -- and automated teller machines fill in where brick-and-mortar banks are uneconomic. In the early nineteenth century, banks were not at every street corner. Legislators and other regulators limited entry so that having a bank was a point of pride for town boosters and represented a prized asset for local merchants, manufacturers and other business people. In 1828, for instance, just prior to New York's modest liberalization of bank chartering in 1829, just 2.7 percent of its towns had a bank. A second liberalization of bank chartering (free banking) was enacted in 1838, at which time only 6.2 percent of cities and towns had a bank. ${ }^{9}$ Even as late as 1860, after two decades of liberal bank chartering and economic expansion, only 15.6 percent of cities and towns had a bank. Potential borrowers in places without a bank were not cut off from bank lending, of course, but lending is (and was) an information-intensive activity (Diamond 1984). Proximity to a banker was not a necessary condition for obtaining a loan, but to the extent that proximity was related to the banker's confidence in the quality of his information, proximity and access to external finance were correlated. Given the nature of nineteenth-century banking, local and distant banks were not perfect substitutes. A bank's benefits may have spilled over to neighboring towns, but our model assumes that the benefits are highly localized. ${ }^{10}$

The Erie Canal and its feeders reshaped New York's economy, remade the urban landscape by facilitating the movement of people and information, and prompted other states to copy New York's ambitious canal program (Sokoloff 1988). Few of the subsequent canals were as successful as the Erie, and not a few were financial boondoggles (Wallis 2003). To account

\footnotetext{
${ }^{8}$ Gorton (1996) provides a model and evidence that the market for bank-issued currency was geographically compact. Notes tended to circulate relatively proximate to the issuing bank, though they sometimes wandered outside their neighborhood.

${ }^{9}$ New York's Safety Fund Act (1829) instituted a system of bank liability co-insurance designed to protect note holders from losses following from bank failure. It was a brief experiment replaced by Free Banking in 1838. Free banking instituted bond-secured note issue to protect shareholders and allowed relatively free entry. After a rocky start, free banking proved to be a durable and relatively stable system when properly regulated. See Bodenhorn (2003) and sources cited therein for details of the systems.

${ }^{10}$ In an earlier draft we controlled for spatial correlation in the errors. The results are not substantively different from those reported here.
} 
for the potential for canals to remake a state's urban landscape, we include a dummy variable equal to one if the town in question was proximate to the canal. To locate towns on a canal, we use both contemporary and modern maps, as well as contemporary sources that listed the location of locks and shipping distances between a given place and the canals' termini (Williams 1840; French 1860).

Commercial centers might also grow more rapidly, all else equal, than otherwise comparable towns (Acemoglu, Johnson and Robinson 2005). To account for a town's commercial importance, we include a dummy variable that equals one if the town ever had a custom's house. The US Treasury located customs houses at important international trade centers. New York State, for example, had 11 such places, the largest of which were New York City, Buffalo and Rochester; others were located at port towns on Lake Ontario (e.g., Oswego) and the St. Lawrence River (e.g., Ogdensburg).

Table 2 provides definitions and summary statistics for the variables discussed above, as well as additional variables discussed below. The average annual compound rate of population growth among the 2,642 cities and northeastern cities and towns in the sample is 0.6 percent, from an average base (log) population of 7.2 inhabitants in 1840. Our analysis focuses on four separate measures to capture financial development. Our simplest measure is a dummy variable that equals one if a city/town has a bank, and zero otherwise. Only 5.6 percent of northeastern cities and towns had a bank between 1837 and 1839, which is a notable difference between the nineteenth-century and modern United States. The legislative chartering prerogative combined with a widespread scepticism of finance and banking insured that only a modest fraction of cities and towns had a bank. It was not until the late nineteenth and early twentieth century that banks proliferated under the liberal chartering rules established by the National Banking Act (1864) and its subsequent amendments. Because so few towns has banks it is not surprising that average log bank assets per town (circa 1838) amounted to just $\$ 0.80$; total bank assets per capita were $\$ 40.61$ but, given the small fraction of towns without a bank, the modal value was $\$ 0 .{ }^{11}$ Bank money per capita (banknotes in circulation plus deposits) averaged $\$ 18.73$ circa 1838 , also with a mode of $\$ 0$.

11 Compare the circa 1840 value in the northeastern United States (the most financially developed region) to other eras. In 1900, the national average total assets per capita were $\$ 141.9$ and deposits per capita were \$112. By 2013, the values increased to $\$ 41,637$ in total bank assets per capita and $\$ 29,108$ in deposits per capita (Board of Governors 2013; United States Department of Commerce 1960, pp. 5, 437). 
We follow Beeson et al (2001) in including the shares of town population employed in the principal sectors (the excluded category is agriculture) to control for initial levels of economic development, but they may also proxy for other features of local economies. The fraction employed in professions (medicine and law, primarily) and commerce (trade, insurance, finance) may partly capture the effects of initial levels of human capital, which Simon and Nardinelli (2002) find to be important contributors to city growth. The fraction employed in mining proxies for local resource endowments, which Glaeser et al (2012) find predicts urbanization. And fraction employed in navigation proxies for access to water, which Beeson et al (2001) find still matters even in the twentieth century. Finally, about six percent of northeastern cities were proximate to a canal and one percent was of sufficient commercial importance to merit customs houses, most of which were on the Atlantic coast.

\section{Empirical Analysis}

In this section we use the data described above to examine the influence of several geographic and economic factors, principally banks, on population growth across midnineteenth-century cities, towns and villages in the northeastern United States.

\subsection{Identification strategy}

We exploit intercity variation in banks and bank lending to identify their effects on the residential choices of nineteenth-century Americans. There are two concerns. First, banks were not allocated randomly across cities and towns. Certain features of local markets surely made some locations preferable to others. During the relevant period of our study (circa-1838), prospective bankers could not freely choose when and where they established a bank. Legislatures retained the chartering prerogative up to the so-called Free Banking Era (18381863). Under the prerogative, prospective bankers petitioned the legislature for a commercial bank charter. A charter was vital to engage in commercial banking, the defining characteristics of which were taking deposits and issuing notes.

Political rather than economic considerations were the driving force behind bank location decisions in several northeastern states. The demand for banking after the First Bank of the United States closed in 1811, led Pennsylvania to pass its Omnibus Bank Act of 1814. The act

divided the state into 17 regions, each of which received at least one bank charter. The economic 
logic of some locations were obvious (Philadelphia, Pittsburgh, Lancaster, Allentown); others were less obvious to modern eyes, and appear to be driven more by logrolling and other political than economic considerations. Bedford, with 547 inhabitants in 1810 got a bank; it had 2,333 inhabitants in 1870. Similarly, Brownsville, with 698 inhabitants in 1810 got a bank; the town had 286 residents in 1870. If Pennsylvania legislators chose to locate banks in places they expected to grow into urban metropolises, their predictions were sometimes quite poor. ${ }^{12}$ Bodenhorn (2006) documents the extent to which political favors determined bank location in pre-1838 New York. The dominant political coalition, led by Martin Van Buren and William Marcy, distributed bank charters to political allies as political spoils. William Marcy, in fact, coined the much-paraphrased term "to the victor go the spoils" during a contentious debate surrounding the distribution of bank charters in the Jacksonian era.

The politics surrounding the distribution of bank charters and the location of banks led us to explore several political, economic and demographic variables that might be used as instruments to predict which cities and towns had a bank. Extensive searches of historical and archival sources failed to generate potential instruments that pass the plausibility criterion, standard statistical tests of exogeneity, and/or the weak instrument test. We do not, however, rely solely on the poor predictive capacity of politicians as an identification strategy. Given our inability to instrument for bank location, we employ propensity score matching to identify causal effects. Although an imperfect solution to the endogeneity problem, the OLS and propensity score matching results yield results of comparable magnitude, which suggests that the OLS estimates are not highly biased.

A second possible concern arises if the he effect of migration (either in or out) led banks to relocate to more promising places. A bank charter specified the city or town in which a bank would locate and amending the charter so that it could relocate required new legislation. Relocating a bank was costly and time-consuming and was authorized only a handful of times between 1820 and 1860. Banks, once situated, could not tap into a fast-growing market through the establishment of branches. Northeastern states generally adopted unit banking laws. Two Philadelphia banks opened branches in the 1810s, but closed them in the 1820s when they found it was difficult to manage them (Holdsworth 1928). Existing banks could not endogenously respond to changes in migration and town growth. That is, each bank was a separate legal and

\footnotetext{
${ }^{12}$ Scores of similarly perplexing bank location choices can be identified in other states, as well.
} 
economic entity. Existing banks could not readily respond to population changes by opening a branch in another town. Thus, the locations of early Northeastern banks, once situated, while not set in stone, were relatively immobile and catered primarily to local clients.

\subsection{Model specification and OLS results}

We begin our empirical exercise by investigating the population growth inducing effects of finance using simple ordinary least squares (OLS) regressions. The dependent variable is the continuously compounded annual average population growth rate between an initial census year 1840 and the terminal year 1870. The independent variables of principal interest are: a dummy variable equal to one if the town in question had an operating bank at any time up to an including the initial census year; and alternative measures of bank size including the (log) of bank assets in the initial year, per capita value of loans outstanding at the initial year, or the per capita value of bank money in the initial year. The first measure is admittedly crude, but accounts for the mere presence of a bank; the other measures capture the marginal effect of banking activity on town growth.

Estimated equations take the following general form:

$$
G_{i j t}=X^{\prime} \beta_{i j t}+\varphi F_{i j t}+\gamma_{j}+\varepsilon_{i j t}
$$

where $G$ is growth rate of city $i$ in state $j$ between time $t$ and $1870, X$ is a vector of controls (natural logarithm of population at time $t$, initial sectoral employment, location on a canal, and customs house dummy variable); $F$ is the relevant measure of financial development (bank dummy, natural logarithm of loans, per capita loans, or per capita deposits) and the feature of principal interest; $\gamma$ are time-invariant state fixed effects; and $\varepsilon$ is the error term.

Coefficient estimates from four alternative specifications are reported in Table 3. The first column uses a dummy variable equal to one if the town has at least one bank as the measure of banking. The coefficient implies that the presence of a bank in the late 1830s increased the annual average growth rate between 1840 and 1870 by 1.3 percentage points. With a mean compound growth rate of just $0.6 \%$ (see Table 2), the banking coefficient is not only statistically significant, but economically meaningful. The mere presence of a bank circa 1838 meant that a town with a bank experienced population growth more than double the mean rate or growth. The estimated coefficient on $\log$ (Total Assets) in Column 2 implies that a one percent increase in bank assets increased the growth rate by 0.1 percent. Similarly, Column 3 implies that a one 
standard deviation (288.84) increase in per capita bank assets increased a town's population growth rate by 0.25 percentage points and Column 4 implies that a one standard deviation (156.88) increase in per capita bank money increased a town's growth rate by approximately 0.16 percentage points. By any measure, banking had a profound impact on town growth. Greater monetization, which proxies for greater participation in the market and economic modernization more generally, is associated with more rapid growth. The public's willingness to exchange real assets for paper claims to assets is a signal change in the nature of development and, by our estimates, a signal change in urbanization.

Moreover, banking increased a town's or a city's growth rate by more than proximity to a canal. Given that economic historians were, at best, agnostic or, at worst, sceptical of banking's influence on urban growth, the greater magnitude of the banking than the canal effect is notable. Generations of historians give the transportation revolution a central place in the US experience (Taylor 1951; Majewski 2000). The banking coefficients suggest that the financial revolution (Sylla 1998) also deserves a central place in the narrative of nineteenth-century economic and urban development.

Other historians claim that the Jacksonian-era commercial revolution deserves a more central place in any discussion of nineteenth-century economic change than it is typically afforded (Sellers 1992). ${ }^{13}$ Bruchey (1967), Crowther (1976), Taylor (1967) and Acemoglu et al (2005) contend that trade, especially international trade, was an important driver of growth in the early stages of economic and urban development. Our estimates also point toward the importance of commerce. The evidence here is consistent with these interpretations: a one standard deviation increase in commercial employment is associated with a 1.3 to 1.7 percentage point increase in a city's annual average growth rate between 1840 and 1870. And the presence of a custom's house, which speaks to a city's importance as an international trade center, is consistent with a 1.9 to 2.4 percentage point increase in a city's growth rate. Cities and towns on the Atlantic coast with protected harbors, such as New York City, grew more rapidly than places with lesser geographic advantages (Albion 1939).

The industrial revolution is unquestionably the century's fundamental economic transformation (Atack and Passell 1994; Hughes 1990), though Lindstrom and Sharpless (1978) argue that a city's industrial composition was a less important determinant of its subsequent

\footnotetext{
${ }^{13}$ Majewski (1997) argues that Seller's (1991) case for the commercial revolution is less than compelling.
} 
growth than is often posited. Our measure of the penetration of the industrial revolution - the proportion of a town's labor force employed in manufacturing in 1840 - reveals that economic modernization was an important determinant of subsequent town growth. The 0.02 coefficient in Column 1 implies that a one standard deviation (0.17) increase in the fraction of the labor force employed in manufacturing in 1840 is associated with a 0.34 percentage point increase in a town's population growth rate in the subsequent three decades. Initial levels of manufacturing signalled impending economic growth, but the effect was smaller than the banking effect. Our

results also reveal that greater proportional commercial employment, as well as more mining activity also had economically meaningful and statistically significant effects on town growth. Larger initial shares of professional and navigation employment did not.

Our baseline OLS estimates show that urban features that an earlier generation of economic historians identified as important drivers of urban growth are, in fact, important. Initially larger places experienced lower percentage increases (a population analogue of the convergence phenomenon identified in the economic growth literature (Barro and Sala-i-Martin 1992, Beeson et al 2001). Transportation infrastructure mattered, as did trade connections and manufacturing and commercial employment. But even after accounting for these other factors, the mere presence of a bank influenced the pace of subsequent population growth and our estimates suggest banking may have been at least as important as the so-called real economy factors.

\subsection{Propensity score matching estimates}

As Dehejia and Wahba (2002) and Angrist and Pischke (2009) note, drawing causal inferences about a treatment effect from observational studies is problematic. Unlike laboratory experiments where units of observations are randomly assigned to treatment and control groups, observational studies are subject to unknown selection. In the case at hand, it is hard to imagine that banks were randomly assigned (relative to their growth potentials) to cities and towns. Even if political considerations altered assignments from what they would have been had other criteria (such as the cities' realized or expected economic importance) been used to locate banks it is not clear that politicians would not have considered a place's prospects before chartering a bank and were not more often correct than not. Various methods can be used to correct for nonrandom treatments. If one or more instruments that predict treatment can be identified, instrumental 
variables methods might be used to solve the identification problem. When no plausible instrument is available, propensity score matching may correct for selection bias in the treatment.

The basics of propensity score matching are now well known, but the essence of the procedure is to use observable covariates in a parsimonious logit or probit specification to estimate a propensity score. Observations are then sorted by the estimated propensity score and observational units (cities and towns) from both the treated (bank) and comparison (no bank) groups are compared on the basis of observable covariates. The average treatment effect on the treated (ATT) can be calculated by comparing the relevant strata of treated and control cities and towns among subsets of cities and town for which the means of the observable characteristics in the treated and control group are not significantly different.

We report results using each of the four widely used methods. The first is the Nearest Neighbor, which consists of taking each treated city and searching for the untreated cities with the closest propensity score. ${ }^{14}$ Once a match is identified, differences in growth rates between the treated and untreated cities are calculated. The reported average treatment on the treated (ATT) is the average of these differences. One problem with this method is that, because all treated cities are matched, the match is sometimes poor. The Radius Matching and Kernel Matching methods solve the poor match problem by only matching cities and towns within a given distance (radius matching) or by weighting the matches based on the distance between the treated and control towns (kernel matching). Finally, the Stratification method divides the range of variation in the propensity score in different intervals such that the treated and control cities have the same propensity score within each of these intervals. The ATT is calculated as an average of the weighted average of the ATT's of each block (Becker and Ichino 2002).

Table 4- provides our estimates of the ATT based on each of the four methods, with having a bank circa 1838 as the treatment. With the exception of the stratification method, which generates an ATT about half the size of the OLS estimate (Table 3, Column 1), the nearest neighbor, radius and kernel estimators are of the same order of magnitude. Having a bank in the late 1830 s led to an increase in a city or town's subsequent annual compound growth rate by about 0.9 to 1.7 percentage points.

\footnotetext{
14 This method is normally implemented with replacement, so that a control city can be matched to more than one treated unit.
} 


\subsection{Politics and bank location: Pennsylvania as a case study}

By 1803 Pennsylvania had chartered only four banks all of which operated in Philadelphia. The state legislature's refusal to charter banks outside Philadelphia had two consequences: prospective bankers repeatedly petitioned for charters; and, financial services were provided by small, unincorporated, largely unregulated private banks, exchange brokers and personal lending networks. In 1810 a group of entrepreneurs opened the Bank of Pittsburgh without a charter and in defiance of a law restraining unchartered, joint-stock banking. The Bank of Northern Liberties in Philadelphia did the same. When the legislature passed a new restraining act, both banks requested charters and were denied. The Bank of Northern Liberties continued undeterred; the Bank of Pittsburgh changed its name to the Pittsburgh Manufacturing Company and it, too, continued operating behind a façade. Despite growing demand for finance, the legislature remained deadlocked and, for several sessions, failed to push any bank chartering bills through the entire process from bill to executive concurrence. ${ }^{15}$

The 1811 closing of the First Bank of the United States located in Philadelphia created a new impetus for state-chartered banking, but the legislature did not respond until 1814 when it passed the Omnibus Banking Act of 1814. The act divided state into 27 banking districts, each of which received at least one bank. Philadelphia got three, including a charter for the alreadyoperating Bank of Northern Liberties; the Lancaster district got five; the Dauphin district (Harrisburg vicinity), the Cumberland district (Carlisle vicinity), and the Franklin district (Chambersburg vicinity) each got two. All told, the act authorized 41 banks, some of which, like Northern Liberties, were already operating extralegally; 39 of them eventually opened. ${ }^{16}$ The act imposed most of the usual charter terms: it specified the town in which each bank would locate, provided the names under which they would operate, determined the initial capitalization, set maximum allowable interest rates, minimum banknote denominations, and imposed a tax on dividends, which the banks were required to distribute at least once each year.

As we noted above, some of the legislature's location choices are, in retrospect, perplexing. The legislature's decision to locate banks in Pittsburgh, Lancaster and Harrisburg,

\footnotetext{
${ }^{15}$ The discussion of Pennsylvania banking follows Holdsworth (1928), Knox (1900), Bodenhorn (2000) and Bodenhorn (2008).

${ }^{16}$ Weber's (2011b) census identifies 38 bank openings between 1814 and 1817; Holdsworth claims 39 opened.
} 
among other places, was obvious, but locations in Bellefonte (303 inhabitants), Lewiston (474 inhabitants) and Meadville (457 inhabitants), which was between Erie and Pittsburgh, described as a good place to grow corn, and without much economic activity until the French Creek Canal passed through in 1837, were less obvious places to locate a bank. As late as 1832, Gordon's (1832, 289) Pennsylvania gazetteer explained that locals anticipated that completion of the proposed canal might yet transform the town into an important trade center. Three banks' charters were eventually revoked for failing to pay dividends (and taxes); 17 more failed during or after the financial panic of 1819. Getting a bank was no guarantee of success, but some of the less obvious locations thrived (relatively) after the banks' arrivals.

After passage of the 1814 Omnibus Banking Act, Pennsylvania reverted back to its previous inability to enact bank chartering legislation. Only six banks were chartered in the 1820 s, three of which were in Philadelphia. During the 1830s, when other states in the northeastern United States opened scores of banks, and New York enacted so-called free banking, Pennsylvania chartered only 20, four of which opened in Philadelphia. Given its historical reluctance to open banks, we use Pennsylvania as a case study because it is reasonable to think that banking was not a completely endogenous response to anticipated population growth. Banks certainly did not spring up anywhere people congregated.

The OLS estimates of equation (8) for the case of Pennsylvania are displayed in Table 5. As in Table 3, in the first column we use a dummy variable equal to one if the town has at least a bank as a proxy for local financial development. The OLS estimate of 0.022 implies that the presence of a bank in the late 1830s is associated with an increase in annual growth rate between 1840 and 1870 of 2.2 percentage points, significantly larger than what we found when we used data for the nine states (1.4 percentage points). The coefficients associated with columns (2)-(4) indicate that a one-standard deviation increase in the different banking indicators is associated with an increase in urban population growth by about 0.2 percentage points.

Table 6 provides our propensity score matching estimates of the average treatment effect on the treated (ATT) for the Pennsylvania subsample. Because the radius and kernel matching procedures failed to return matched towns, we report only the nearest neighbor and stratification results. Both point toward substantial effects of banking on town growth, though the small number of matches for the stratification procedure reduces our confidence in that estimate. Still, the estimates imply an incremental growth rate of 2-3 percentage points, which is slightly higher 
than the 0.6 to 1.5 percentage point effect estimated for the larger Northeast sample. Banks and the services they provided were an independent source of urban development and growth and were every bit as important as canals, access to waterways, and other natural and man-made locational advantages.

\section{Concluding remarks}

Evidence from the nineteenth-century northeastern United States supports the hypothesis that financial development positively influences urbanization and city growth. Jaremski and Rousseau (2012), using county-level data, find that the mere presence of a bank in 1850 or 1860 increases county-level urbanization in the subsequent decade. One contribution of our study, then, is that it shows that the effect they uncover at the county level applies to individual cities and towns and that it unfolds over relatively long periods. In the northeastern United States, at least, banks substantially increased the annual average rate of town population growth in the three decades between 1840 and 1870. Regardless of the measure of banking used, the availability of finance increased urban growth. The mere presence of a bank increased annual growth rates by about one percentage point.

Contemporary observers noted that nineteenth-century Americans were a people on the make - bartering, trading, speculating, and "smart dealing" - behavior that, like their forever spitting everywhere, not everyone found endearing (Dickens 1850. p. 171). Given the contemporary Americans' propensity to trade, it is not surprising that places providing financial services attracted more people, especially those of an enterprising or speculating bent. ${ }^{17}$ The question of which cities attracted migrants was answered, in part, by the answer to a different question: where are the banks? There are any number of reasons why an individual might find a location appealing; it might have good schools, beautiful views, good employment opportunities or access to water. Our study finds that places with banks were incrementally more attractive destinations than places without, all else the same. Economic historians have connected the ideas

\footnotetext{
17 Dickens traveled the United States in 1842 . The country had just passed through two banking crises (1837 and 1839) and remained in the throes of an extended recession. His interpretations of American's financial dealings and market morality sound thoroughly modern and would surely resonate with participants in the so-called "Occupy" movement of 2011/12. A trader's reputation was based more on "smartness" of his deals than with their ethics or consequences. As Dickens (1850, p. 117) wrote, all "this smartness has done more in a few years to impair the public credit, and to cripple the public resources, than dull honesty."
} 
of an early nineteenth-century financial revolution and the finance-growth literature to posit that finance mattered in the process of economic development and modernization. Our study adds a new wrinkle to that conclusion; finance also mattered to the process of urbanization, population growth and the agglomeration of economic activity.

\section{References}

Acemoglu, Daron, Simon Johnson and James Robinson. 2005. "The Rise of Europe: Atlantic Trade, Institutional Change and Growth.” American Economic Review 95(3), 546-579.

Albion, Robert G. 1939. The Rise of New York Port, 1815-1860. New York: Charles Scribner's Sons.

Albouy, David. 2008. “Are Big Cities Really Bad Places to Live? Improving Quality of Life Estimates Across Cities.” Working Paper 14472, National Bureau of Economic Research.

Alonso,William. 1964. Location and Land Use; Toward a General Theory of Land Rent. Cambridge, MA: Harvard University Press.

Allen, Franklin and Douglas Gale. 1997. "Financial Markets, Intermediaries, and Intertemporal Smoothing." Journal of Political Economy 105.3, 523-546.

Angrist, Joshua D and Jörn-Steffen Pischke. 2009. Mostly Harmless Econometrics: An Empiricist's Companion. Princeton: Princeton University Press.

Ashmead, H. G. 1914. History of the Delaware County National Bank with Biographical Notes of Its Officers. Chester, Penn.: privately printed.

Atack, Jeremy and Peter Passell. 1994. A New Economic View of American History from Colonial Times to 1940. New York: W. W. Norton \& Company.

Barro, Robert and Xavier Sala-i-Martin. 1992. "Convergence.” Journal of Political Economy $100.2,223-251$.

Becker, S and A. Ichino. 2002. "Estimation of Average Treatment Effects Based on Propensity Scores." The Stata Journal 2(4), 358-377.

Beeson, Patricia E., david N. DeJong, and Werner Troesken. 2001. "Population Growth in U.S. Counties, 1840-1990." Regional Science and Urban Economics 31(6), 669-699. 
Benfratello, L., F. Schiantarelli, and A. Sembenelli (2008), "Banks and Innovation: Microeconometric Evidence on Italian Firms." Journal of Financial Economics 90(2), pp. 197-217.

Benson, Lee. 1961. The Concept of Jacksonian Democracy: New York as a Test Case. Princeton: Princeton University Press.

Bernstein, Peter L. 2005. Wedding of the Waters: The Erie Canal and the Making of a Great Nation. New York and London: W. W. Norton \& Company.

Board of Governors of the Federal Reserve System. 2013. Assets and Liabilities of Commercial Banks (Weekly) - H.8. (Release date: November 22, 2013). www . federalreserve.gov / releases/h8/current. (Accessed November 25, 2013).

Bodenhorn, Howard. 2000. A History of Banking in Antebellum America: Financial Markets and Economic Development in an Era of Nation-Building. Cambridge: Cambridge Unversity Press.

Bodenhorn, Howard. 2003. State Banking in Early America: A New Economic History. Oxford and New York: Oxford University Press.

Bodenhorn, Howard. 2006. "Bank Chartering and Political Corruption in Antebellum New York: Free Banking as Reform.” In Corruption and Reform: Lessons from America's Economic History, 231-258. Edited by Edward L. Glaeser and Claudia Goldin. Chicago: University of Chicago Press.

Bodenhorn, Howard. 2008. "Free Banking and Bank Entry in Nineteenth-Century New York." Financial History Review 15(2), 175-201.

Bodenhorn, Howard and Hugh Rockoff. 1992. "Regional Interest Rates in Antebellum America." In Strategic Factors in American Economic History: A Volume to Honor Robert W. Fogel, 159-187. Edited by Claudia Goldin and Hugh Rockoff. Chicago: University of Chicago Press, 1992.

Bruchey, Stuart. 1967. Cotton and the Growth of the American Economy. New York: Harcourt, Brace \& World.

Carlino, Gerald A. and Albert Saiz. 2008. “City Beautiful.” Working Paper 08-22, Federal Reserve Bank of Philadelphia. 
Chen, Henry, Paul Gompers, Anna Kovner, and Josh Lerner. 2010. "Buy Local? The Geography of Venture Capital." Journal of Urban Economics 67(1), 90-102.

Chinitz, Benjamin. (1961), Contrasts in Agglomeration: New York and Pittsburgh, American Economic Review: Papers and Proceedings, 279-289, reprinted in: M. Edel and J. Rothenberg (Eds) (1972) Readings in Urban Economics, 90-99. New York: Macmillan.

Ciccone, Antonio and Robert E. Hall. 1996. "Productivity and the Density of Economic Activity." American Economic Review 86(1):54-70.

Cingano, Federico and Fabiano Schivardi. 2004. "Identifying the Sources of Local Productivity Growth." Journal of the European Economic Association 2(4):720-742.

Combes, Pierre Philippe, Gilles Duranton, Laurent Gobillon, and Sébastien Roux. 2010. "Estimating Agglomeration Effects with History, Geology, and Worker Fixed Effects. In Edward L. Glaeser (ed.) Agglomeration Economics. Chicago, il: Chicago University Press, 15-65.

Crothers, A. G. 1999.)-, "Banks and Economic Development in Post-Revolutionary Northern Virginia, 1790-1812." Business History Review 73(1), 1-39.

Crowther, Simeon J. 1976. "Urban Growth in the Mid-Atlantic States, 1785-1850." Journal of Economic History 36(3), 632-640.

Cuberes, David. 2009. “A Model of Sequential City Growth,” The B.E. Journal of Macroeconomics: March 2009, Vol. 9: Iss. 1 (Contributions), Article 18.

Deheija, Rajeev H. and Sadek Wahba (2002), "Propensity Score-Matching Methods for Nonexperimental Causal Studies." Review of Economics and Statistics 84(1), February, pp. 151-61.

Demirguc-Kunt, Asli and Ross Levine. 2001. "Financial Structure and Economic Growth: Perspectives and Lessons." Financial Structure and Economic Growth: A Cross-Country Comparison of Banks, Markets, and Development. Edited by Asli Demirguc-Kunt and Ross Levine. Cambridge: MIT Press.

Diamond, Douglas W. 1984. "Financial Intermediation and Delegated Monitoring." Review of Economic Studies 51(3), 393-414.

Diamond, Douglas W. 1991. "Monitoring and Reputation: The Choice between Bank Loans and Directly Placed Debt.” Journal of Political Economy 99(4), 689-721.

Dickens, Charles. 1850. American Notes for General Circulation. London: Chapman and Hall. 
Duranton, Gilles and Diego Puga. 2004. "Micro-Foundations of Urban Agglomeration Economies," Handbook of Regional and Urban Economics, in: J. V. Henderson \& J. F. Thisse (ed.), Handbook of Regional and Urban Economics, edition 1, volume 4, chapter 48, 2063-2117 Elsevier.

Duranton, Gilles and Diego Puga. 2013a. "The Growth of Cities.” CEPR Discussion Paper No. DP9590.

Duranton, Gilles and Diego Puga. 2013b. "Urban Growth: Systematic, Idiosyncratic and Random Determinants and their Aggregate Implications.” Processed, Wharton School, University of Pennsylvania.

French, J. H. 1860. Gazetteer of the State of New York. Syracuse: R. Pearsall Smith.

Fulford, Scott. 2012. "If Financial Development Matters, Then How? National Banks in the United States, 1870-1900.” Working paper, Boston University.Glaeser, Edward L. 2011. Triumph of the City: How Our Greatest Invention Makes Us Richer, Smarter, Greener, Healthier, and Happier. New York: Penguin Press.

Glaeser, Edward L. and Joshua D. Gottlieb. 2009. “The Wealth of Cities: Agglomeration Economies and Spatial Equilibrium in the United States.” Journal of Economic Literature 47(4), 983-1028.

Glaeser, Edward L. and Albert Saiz. 2004. "The Rise of the Skilled City.” Brookings Wharton Papers on Urban Affairs 5:47-95.

Glaeser, Edward L. and William R. Kerr. 2009. "Local Industrial Conditions and Entrepreneurship: How Much of the Spatial Distribution Can We Explain?" Journal of Economics and Management Strategy 18(3):623-663.

Glaeser, Edward L., Heidi Kallal, José A. Scheinkman, and Andrei Schleifer. 1992. "Growth in Cities." Journal of Political Economy 100(6):1126-1152.

Glaeser, Edward L., Sari Pekkala Kerr, and William R. Kerr. 2012. "Entrepreneurship and Urban Growth: An Empirical Assessment with Historical Mines.” NBER working paper 18333.

Glaeser, Edward L., Jed Kolko, and Albert Saiz. 2001. "Consumer City.” Journal of Economic Geography 1(1)L 27-50.

Glaeser, Edward L., Stuart S. Rosenthal and William C. Strange. 2010. "Urban Economics and Entrepreneurship," Journal of Urban Economics 67(1), 1-14, January. 
Glaeser, Edward L., JoséA. Scheinkman, and Andrei Shleifer. 1995. "Economic Growth in a Cross-Section of Cities.” Journal of Monetary Economics 36(1), 117-143.

Gordon, Thomas F. 1832. A Gazetteer of the State of Pennsylvania. Philadelphia: T. Belknap.

Haines, Michael R. 2001. "The Urban Mortality Transition in the United States, 1800-1940." NBER working paper H134.

Haines, Michael R. 2006. United States Census - Minor Civil Divisions Files, 1790-1870. Unpublished data files. Colgate University.

Holdsworth, John Thom. 1928. Financing an Empire: History of Banking in Pennsylvania. Chicago: S. J. Clarke Publishing Company.

Hughes, Jonathan. 1990. American Economic History. 3d ed. Glenview, Ill.: Scott, Foresman/Little Brown.

Jaremski, Matthew S. and Peter L. Rousseau. 2013. "Banks, Free Banks, and U.S. Economic Growth.” Economic Inquiry 51(2), 1603-1621.

Kendall, Jake. "Local Financial Development and Growth." Journal of Banking \& Finance $36(5), 1548-1562$.

Kim, Sukkoo. 2000. "Urban Development in the United States, 1690-1990." Southern Economic Journal 66(4), 855-880.

Knox, John Jay. 1900. A History of Banking in the United States. New York: Bradford Rhodes and Company.

Kroos, H. E. (1967), "Financial Institutions." In The Growth of the Seaport Cities, 1790-1825, pp. 104-138. Edited by D.T. Gilchrist. Charlottesville: University Press of Virginia.

Levine, Ross. 1997. "Financial Development and Economic Growth: Views and Agenda." Journal of Economic Literature 35(2), 688-726.

Levine, Ross. 2005. "Finance and Growth: Theory and Evidence." Handbook of Economic Growth. Edited by Phillipe Aghion and Steven Durlauf. The Netherlands: Elsevier Science.

Lindstrom, Diane and John Sharpless. 1978. "Urban Growth and Economic Structure in Antebellum America." Research in Economic History 3, 169-185.

Majewski, John. 1997. “A Revolution Too Many?” Journal of Economic History 57(2), 476-480.

Majewski, John. 2000. A House Dividing: Economic Development in Pennsylvania and Virginia before the Civil War. New York: Cambridge University Press. 
Marshall, Alfred. 1895. Principles of Economics. Vol. 1. Third Edition. London and New York: Macmillan and Co.

McKinnon, Ronald I. 1973. Money and Capital in Economic Development. Washington, D.C.: Brookings Institute.

Mills, Edwin S. 1967. "An Aggregative Model of Resource Allocation in a Metropolitan Area.” American Economic Review Papers and Proceedings 57(2):197-210.

Muth, Richard F. 1969. Cities and Housing. Chicago: University of Chicago Press.

Schumpeter, Joseph A. 1934. The Theory of Economic Development: An Inquiry into Profit, Capital, Credit, Interest, and the Business Cycle. Cambridge: Harvard University Press.

Sellers, Charles. 1992. The Market Revolution: Jacksonian America, 1815-1846. New York: Oxford University Press.

Shaw, Edward S. 1973. Financial Deepening in Economic Development. New York: Oxford University Press.

Simon, Curtis J and Clark Nardinelli. 1996. "The Talk of the Town: Human Capital, Information, and the Growth of English Cities, 1861 to 1961. Explorations in Economic History 33(3):384-413.

Simon, Curtis J and Clark Nardinelli. 2002. "Human Capital and the Rise of American Cities, 1900-1990." Regional Science and Urban Economics 32(1), 59-96.

Sokoloff, Kenneth L. 1988. "Inventive Activity in Early Industrial America: Evidence from the Patent Records, 1790-1846." Journal of Economic History 48(4), 813-850.

Sylla, Richard. 1998. "U.S. Securities Markets and the Banking System, 1790-1840." Federal Reserve Bank of St. Louis Review, 83-98.

Taylor, George Rogers. 1951. The Transportation Revolution, 1815-1860. New York: Holt, Rinehart and Winston.

Taylor, G. R. (1967), “American Urban Growth Preceding the Railway Age." Journal of Economic History 27(3), pp. 309-39.

United States Department of Commerce. Bureau of the Census. 1960. Statistical Abstract of the United States: 1960. (Eighty-first edition.) Washington, D.C.: Government Printing Office.

Vitiello, Domenic. 2013. Engineering Philadelphia: The Sellers Family and the Industrial Metropolis. Ithaca and London: Cornell University Press. 
Wallis, John J. 2003. “The Property Tax as a Coordinating Device: Financing Indiana's Mammoth System of Internal Improvements, 1835-1842." Explorations in Economic History 40(3), 223-250.

Weber, Warren E. 2006. "Early State Banks in the United States: How Many Were There and When Did They Exist?” Journal of Economic History xx(x), pp. 433-455.

Weber, Warren E. 2011a. Census of State Banks. Research Department, Federal Reserve Bank of Minneapolis.

Weber, Warren E. 2011b. Balance sheets for U.S. Antebellum State Banks. Research Department, Federal Reserve Bank of Minneapolis.

Weiman, David F. 1988. "Urban Growth on the Periphery of the Antebellum Cotton Belt: Atlanta, 1847-1860." Journal of Economic History 48(2), 259-272.

Williams, Edwin. 1833. The New York Annual Register for the Year of Our Lord 1833. New York: Peter Hill.

Williams, Edwin. 1840. The New York Annual Register for the Year of Our Lord 1840. New York: Stationers' Hall. 
Table 1

Panel A: Town Populations

$\begin{array}{lrrr}\begin{array}{l}\text { Population } \\ \text { Range }\end{array} & \begin{array}{c}1820 \\ \text { pop }\end{array} & \begin{array}{c}1840 \\ \text { pop }\end{array} & \begin{array}{c}1870 \\ \text { pop }\end{array} \\ <2,500 & 2008 & 2505 & 3253 \\ 2,500-4,999 & 331 & 474 & 676 \\ 5,000-9,999 & 47 & 84 & 175 \\ 10,000-24,999 & 3 & 19 & 75 \\ 25,000-49,999 & 2 & 1 & 18 \\ 50,000-99,999 & 0 & 1 & 8 \\ 100,000-249,999 & 2 & 0 & 3 \\ 250,000+ & 0 & 2 & 4\end{array}$

Panel B: Employment shares by town

$\begin{array}{lcccc}\begin{array}{l}\text { Population } \\ \text { Range }\end{array} & \begin{array}{c}1820 \\ \% \mathrm{mfg}\end{array} & \begin{array}{c}1820 \\ \% \text { com }\end{array} & \begin{array}{c}1840 \\ \% \mathrm{mfg}\end{array} & \begin{array}{c}1840 \\ \% \text { com }\end{array} \\ & & & & \\ <2,500 & 0.2 & 0.03 & 0.2 & 0.02 \\ 2,500-4,999 & 0.24 & 0.04 & 0.27 & 0.02 \\ 5,000-9,999 & 0.35 & 0.1 & 0.39 & 0.04 \\ 10,000-24,999 & 0.62 & 0.34 & 0.6 & 0.14 \\ 25,000-49,999 & 0.31 & 0.23 & 0.75 & 0.02 \\ 50,000-99,999 & & & 0.28 & 0.11 \\ 100,000-249,999 & 0.69 & 0.28 & & \\ 250,000+ & 0.23 & 0.05 & 0.26 & 0.04\end{array}$


Table 1

Summary statistics

\begin{tabular}{|c|c|}
\hline city population growth $1840-1870$ & $\begin{array}{l}0.006 \\
(0.02)\end{array}$ \\
\hline fraction of towns with a bank $1837-1839$ & 0.056 \\
\hline log bank assets $1837-1839$ & $\begin{array}{c}0.8 \\
(3.3)\end{array}$ \\
\hline assets per capita $1837-1839$ & $\begin{array}{c}40.6 \\
(288.8)\end{array}$ \\
\hline liquidity per capita 1837-1839 & $\begin{array}{c}18.7 \\
(156.9)\end{array}$ \\
\hline log population in 1840 & $\begin{array}{c}7.2 \\
(0.9)\end{array}$ \\
\hline fraction of workforce in manufacturing in 1840 & $\begin{array}{c}0.2 \\
(0.2)\end{array}$ \\
\hline fraction of workforce in agriculture in 1840 & $\begin{array}{c}0.7 \\
(0.2)\end{array}$ \\
\hline fraction of workforce in commerce in 1840 & $\begin{array}{c}0.02 \\
(0.03)\end{array}$ \\
\hline fraction of workforce in professions in 1840 & $\begin{array}{c}0.02 \\
(0.03)\end{array}$ \\
\hline fraction of workforce in mining in 1840 & $\begin{array}{l}0.007 \\
(0.05)\end{array}$ \\
\hline fraction of workforce in navigation in 1840 & $\begin{array}{c}0.02 \\
(0.07)\end{array}$ \\
\hline fraction of towns with a canal & 0.06 \\
\hline fraction of towns with a cl & 0.01 \\
\hline
\end{tabular}

Notes: $\mathrm{N}=3086$ towns existing in 1840

Sources: authors' calculations 
Table 3

Finance and town growth, 1840-1870

OLS estimates

(1)

$$
\begin{gathered}
0.013 * * * \\
(0.002)
\end{gathered}
$$

$\log$ (Total Assets)

Total assets per capita

Bank money per capita

$$
\log (\text { Population 1840) }
$$

$\%$ manufacturing 1840

$\%$ commerce 1840

$\%$ mining 1840

$\%$ professional 1840

$\%$ navigation 1840

Canal (0/1)

Customs house (0/1)

Constant
(2)

\begin{tabular}{|c|c|c|c|c|}
\hline Bank in town $(0 / 1)$ & $\begin{array}{c}0.013 * * * \\
(0.002)\end{array}$ & & & \\
\hline $\log$ (Total Assets) & & $\begin{array}{c}0.001 * * * \\
(0.0001)\end{array}$ & & \\
\hline Total assets per capita & & & $\begin{array}{c}8.72 \mathrm{e}-06 * * * \\
(2.22 \mathrm{e}-06)\end{array}$ & \\
\hline Bank money per capita & & & & $\begin{array}{c}0.00001 * * * \\
(3.65 \mathrm{e}-06)\end{array}$ \\
\hline $\log ($ Population 1840) & $\begin{array}{c}-0.012 * * * \\
(0.0009)\end{array}$ & $\begin{array}{c}-0.012 * * * \\
(0.0009)\end{array}$ & $\begin{array}{c}-0.012 * * * \\
(0.0009)\end{array}$ & $\begin{array}{c}-0.011 * * * \\
(0.0009)\end{array}$ \\
\hline$\%$ manufacturing 1840 & $\begin{array}{c}0.025 * * * \\
(0.003)\end{array}$ & $\begin{array}{c}0.025^{* * *} \\
(0.003)\end{array}$ & $\begin{array}{c}0.027 * * * \\
(0.003)\end{array}$ & $\begin{array}{c}0.028 * * * \\
(0.003)\end{array}$ \\
\hline$\%$ commerce 1840 & $\begin{array}{c}0.042^{* *} \\
(0.02)\end{array}$ & $\begin{array}{c}0.039 * * \\
(0.017)\end{array}$ & $\begin{array}{c}0.054 * * * \\
(0.017)\end{array}$ & $\begin{array}{c}0.056 * * * \\
(0.018)\end{array}$ \\
\hline$\%$ mining 1840 & $\begin{array}{c}0.026 * * \\
(0.01)\end{array}$ & $\begin{array}{c}0.026^{* *} \\
(0.01)\end{array}$ & $\begin{array}{c}0.025 * * \\
(0.012)\end{array}$ & $\begin{array}{c}0.025 * * \\
(0.012)\end{array}$ \\
\hline$\%$ professional 1840 & $\begin{array}{l}-0.02 \\
(0.03)\end{array}$ & $\begin{array}{l}-0.022 \\
(0.025)\end{array}$ & $\begin{array}{l}-0.034 \\
(0.03)\end{array}$ & $\begin{array}{l}-0.025 \\
(0.027)\end{array}$ \\
\hline$\%$ navigation 1840 & $\begin{array}{l}0.0002 \\
(0.005)\end{array}$ & $\begin{array}{l}0.0003 \\
(0.005)\end{array}$ & $\begin{array}{c}0.001 \\
(0.005)\end{array}$ & $\begin{array}{c}0.001 \\
(0.005)\end{array}$ \\
\hline Canal $(0 / 1)$ & $\begin{array}{c}0.004 * * * \\
(0.001)\end{array}$ & $\begin{array}{c}0.004 * * * \\
(0.001)\end{array}$ & $\begin{array}{c}0.003 * * * \\
(0.001)\end{array}$ & $\begin{array}{c}0.004 * * * \\
(0.001)\end{array}$ \\
\hline Customs house $(0 / 1)$ & $\begin{array}{c}0.019 * * * \\
(0.004)\end{array}$ & $\begin{array}{c}0.017 * * * \\
(0.004)\end{array}$ & $\begin{array}{c}0.021 * * * \\
(0.004)\end{array}$ & $\begin{array}{c}0.023 * * * \\
(0.004)\end{array}$ \\
\hline Constant & $\begin{array}{c}0.098 * * * \\
(0.007)\end{array}$ & $\begin{array}{l}0.1 * * * \\
(0.007)\end{array}$ & $\begin{array}{c}0.094 * * * \\
(0.007)\end{array}$ & $\begin{array}{c}0.092 * * * \\
(0.007)\end{array}$ \\
\hline State dummies & Yes & Yes & Yes & Yes \\
\hline R-square & 0.193 & 0.197 & 0.191 & 0.182 \\
\hline Observations & 2778 & 2778 & 2778 & 2778 \\
\hline
\end{tabular}

(3)
(4)

Robust standard errors in parentheses $* * * \mathrm{p}<0.01, * * \mathrm{p}<0.05, * \mathrm{p}<0.1$ 
Table 4

Propensity score matching estimates

initial bank effect on population growth

$\begin{array}{lccc}\text { Estimator } & \text { ATT } & \text { NT } & \text { NC } \\ \text { Nearest Neighbor } & \begin{array}{llll}0.016^{* *} \\ (0.004)\end{array} & 226 & 2120 \\ & 0.009^{* *} & 90 & 613 \\ \text { Radius } & (0.004) & & \\ & 0.017^{* *} & 226 & 2775 \\ \text { Kernel } & (0.006) & & \\ & 0.006^{*} & 113 & 696 \\ \text { Stratification } & (0.004) & & \end{array}$

Note: $* *$ implies p-value $<0.05 ; *$ implies

$\mathrm{p}<0.10$ 
Table 5

Finance and town growth, 1840-1870

OLS estimates. The case of Pennsylvania.
(1)
(2)
(3)
(4)

\begin{tabular}{|c|c|c|c|c|}
\hline Bank in town $(0 / 1)$ & $\begin{array}{c}0.022 * * * \\
(0.005)\end{array}$ & & & \\
\hline $\log$ (Total Assets) & & $\begin{array}{c}0.001 * * * \\
(0.0003)\end{array}$ & & \\
\hline Total assets per capita & & & $\begin{array}{l}5.16 \mathrm{e}-06 * * * \\
1.98 \mathrm{e}-06 * * *\end{array}$ & \\
\hline Bank money per capita & & & & $\begin{array}{c}7.47 \mathrm{e}-06^{* *} \\
(3.25 \mathrm{e}-06)\end{array}$ \\
\hline $\log ($ Population 1840) & $\begin{array}{c}-0.013 * * * \\
(0.001)\end{array}$ & $\begin{array}{c}-0.013 * * * \\
(0.001)\end{array}$ & $\begin{array}{c}-0.013 * * * \\
(0.001)\end{array}$ & $\begin{array}{c}-0.013 * * * \\
(0.001)\end{array}$ \\
\hline$\%$ manufacturing 1840 & $\begin{array}{l}0.01 * * \\
(0.004)\end{array}$ & $\begin{array}{l}0.01 * * \\
(0.004)\end{array}$ & $\begin{array}{c}0.011 * * \\
(0.004)\end{array}$ & $\begin{array}{c}0.011 * * \\
(0.004)\end{array}$ \\
\hline$\%$ commerce 1840 & $\begin{array}{l}-0.038 \\
(0.024)\end{array}$ & $\begin{array}{l}-0.039 * \\
(0.023)\end{array}$ & $\begin{array}{l}-0.039 \\
(0.024)\end{array}$ & $\begin{array}{l}-0.038 \\
(0.025)\end{array}$ \\
\hline$\%$ mining 1840 & $\begin{array}{c}0.018 \\
(0.013)\end{array}$ & $\begin{array}{c}0.018 \\
(0.013)\end{array}$ & $\begin{array}{c}0.018 \\
(0.013)\end{array}$ & $\begin{array}{c}0.018 \\
(0.013)\end{array}$ \\
\hline$\%$ professional 1840 & $\begin{array}{l}0.056^{*} \\
(0.034)\end{array}$ & $\begin{array}{l}0.056^{*} \\
(0.034)\end{array}$ & $\begin{array}{l}0.063 * \\
(0.034)\end{array}$ & $\begin{array}{l}0.065^{*} \\
(0.034)\end{array}$ \\
\hline$\%$ navigation 1840 & $\begin{array}{l}0.05 * * \\
(0.02)\end{array}$ & $\begin{array}{c}0.051 * * \\
(0.02)\end{array}$ & $\begin{array}{l}0.05 * * \\
(0.02)\end{array}$ & $\begin{array}{c}0.049 * * \\
(0.02)\end{array}$ \\
\hline Canal (0/1) & $\begin{array}{c}0.004 \\
(0.003)\end{array}$ & $\begin{array}{c}0.004 \\
(0.003)\end{array}$ & $\begin{array}{l}0.006^{*} \\
(0.003)\end{array}$ & $\begin{array}{l}0.006^{*} \\
(0.003)\end{array}$ \\
\hline Customs house (0/1) & $\begin{array}{c}0.058 * * * \\
(0.015)\end{array}$ & $\begin{array}{c}0.055 * * * \\
(0.014)\end{array}$ & $\begin{array}{c}0.071 * * * \\
(0.012)\end{array}$ & $\begin{array}{c}0.073 * * * \\
(0.013)\end{array}$ \\
\hline Constant & $\begin{array}{c}0.095 * * * \\
(0.007)\end{array}$ & $\begin{array}{c}0.096 * * * \\
(0.007)\end{array}$ & $\begin{array}{c}0.092 * * * \\
(0.008)\end{array}$ & $\begin{array}{c}0.091 * * * \\
(0.008)\end{array}$ \\
\hline State dummies & Yes & Yes & Yes & Yes \\
\hline $\mathrm{R}$-square & 0.287 & 0.289 & 0.272 & 0.269 \\
\hline Observations & 910 & 910 & 910 & 910 \\
\hline
\end{tabular}

Robust standard errors in parentheses $* * * \mathrm{p}<0.01, * * \mathrm{p}<0.05, * \mathrm{p}<0.1$ 
Table 6

Propensity score matching estimates of initial bank effect on population growth.

The case of Pennsylvania

$\begin{array}{lccc}\text { Estimator } & \text { ATT } & \text { NT } & \text { NC } \\ \text { Nearest Neighbor } & 0.02 * & 31 & 895 \\ & (0.01) & & \\ \text { Stratification } & 0.03^{* * *} & 4 & 148 \\ & (0.01) & & \end{array}$

Note: $* * *$ implies $\mathrm{p}$-value $<0.01$. 